\title{
The Characteristics of Teacher Leadership Behaviour in the Class of Physical Health Education (PJOK) at SMA Negeri 1 Simpang Tiga from the Academic Year 2020/2021
}

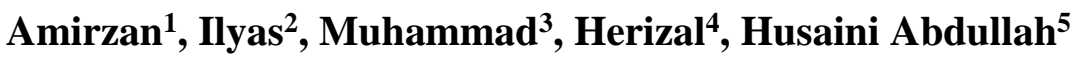 \\ 1,2,3,4,5 Universitas Jabal Ghafur Sigli, Aceh, Indonesia \\ Amirzan@unigha.ac.id,ilyasdaud1965@gmail.com,Muhammad@Unigha.ac.id, \\ herizal_aprc@yahoo.co.id,husaini@unigha.ac.id
}

\begin{abstract}
This research aims to investigate the extent to which the system or leadership style is owned and implemented by Physical Health Education (PJOK) teachers when they teach the students, both theoretical and practice, this is important because success in teaching is strongly influenced by various factors, one of which is the teacher attitude as behavior in the implementation of educational learning which is often referred to as a model or lead character. The data for this qualitative study derives from a questionnaire to 26 respondents namely, school leaders, school administration, students and PJOK teachers in SMA Negeri I Simpang Tiga. While the research question posed is "What type of leadership characteristics are generally the most dominant adopted or implemented by PJOK teachers at SMA Negeri I Simpang Tiga". Based on the results of data processing in the questionnaire, it can be concluded that in general the PJOK teachers at SMA Negeri I Simpang Tiga have implemented a "democratic" leadership type in nature.
\end{abstract}

\section{Keywords}

characteristic; leadership; Physical Health Education (PJOK) teachers

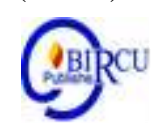

\section{Introduction}

The function of the teacher is as an educator, and then the role is related to increasing the growth and development of students in a process of providing learning experiences from each teaching and learning activity. In this case, it includes physical health, moral development, social responsibility, basic knowledge and skills and other things that are personal and spiritual in the hope that he will become an adult human being.

Aspects of growth or health, discipline, morality and skills, especially movement skills are the main responsibilities of PJOK teachers even though they are also responsible for all aspects of personality development, intelligence, mentality and spirituality which include the realm of education, such as the cognitive domain (thinking process), affective domains (values or attitudes), psychomotor (skills).

From various aspects of determining the success of learning that has been achieved by students, a responsibility that is more directed towards the teachers, this is under the expertise and field of study which is the responsibility or the profession they are involved in. So related to physical skills and student health, it is more the responsibility of the PJOK teachers assigned to the school.

Leadership means being able to lead and be led. The implementation of leadership in PJOK learning can be seen from the beginning to the end of PJOK learning. Here the initial role of the teacher as a role model because one way to teach character effectively is by giving an example. 
Leadership can be defined as a process of directing and giving influence to the activities of a group of members who are related to their duties (Stoner, 1992: 114). According to Gorton et al., Leadership is a characteristic of leaders in influencing subordinates to achieve organizational goals. The success of leadership is partly determined by the ability of leaders to develop their organizational culture. (Arif, 2019).

Azis (2008) says that educational leadership is a quality of activities and integration in educational situations. Educational leadership is the ability to move the implementation of education so that the educational goals set can be achieved effectively and efficiently.

In general, the most dominant leadership models are Autocratic and Democratic Leadership Models. From these leadership models, which leadership model is more dominantly applied by PJOK teachers during learning activities. Because the application of the leadership model carried out by PJOK teachers during Physical Education learning, Health Sports that takes place will affect the success of every learning carried out in schools, both theoretical and practical learning, so teacher leadership is very important to know as the implementation is carried out by the teachers.

The reality that the implementation of PJOK learning at SMA Negeri Kembang Tiga does not run as expected, because when PJOK learning took place many students do not take part in learning, especially during practical learning hours in the field, especially female students, so that many students wandered around at the implementation of PJOK learning, according to the author, is triggered by various factors, but one of them is related to the educational leadership of PJOK teachers, both during practical learning in the field, as well as when learning theory in the classroom.

From the various descriptions that have been previously stated above regarding the very basic problems in this study, are the PJOK teachers at SMA Negeri I Simpang Tiga able to address various problems that may arise during the PJOK learning process? What is the leadership type used by the PJOK teachers at SMA Negeri Simpang Tiga in general? Whether in making various decisions leading to one leadership model or combining several characters or leadership models.

\section{Review of Literature}

\subsection{Physical Education Definition}

Each physical education teaching activity is the responsibility of the implementers, namely Physical Education teachers and students, especially Physical Health Education (PJOK) teachers as teaching leaders. Therefore every PJOK teacher must understand the basic concepts of Physical Education. To understand the concept of Physical Education, below are quoted some opinions from education experts about the meaning of Physical Education. Lutan (2001) explains "Physical Education as an educational process via human movement (human movement) which can be in the form of physical activity, games, or sports to achieve educational goals. In line with the efforts of educational goals, in Physical Education, the individual potential is developed, physical, intellectual, emotional, social and moral-spiritual abilities".

According to Bennett (1983) in Winarno (2006), Physical Health Education is an integral part of education and carries out activities to ensure the overall development of the physical and moral qualities of children at school in preparing for their lives, working and defending their country. More specifically, Physical Health Education will improve health, develop physical skills, potential organs of the body, functional movement skills and instill moral qualities such as patriotism, cooperation, courage, perseverance, and self-confidence 


\subsection{Teacher Definition According to Experts}

1. According to Ball and Forzani (2010) a teacher is required to be able to play a role in showing the ideal teacher image in his community.

2. In this case, Arends (2013), argues that the image of the ideal teacher is aware and responsive to the changing times of his non-routine teacher action patterns, the teacher is advanced in mastering the basic knowledge and instrumental devices (eg systems thinking, scientific reading, problem-solving skills, etc.) needed to be further or sustainable. According to Rice and Bishoprick (1971) in Mulyasa (2009), professional teachers are teachers who can manage themselves in carrying out their daily tasks. Professional teachers by the two experts are seen as a process that moves from ignorance to knowledge, from immaturity to maturity, from being directed by others to being self-directed.

3. In Law No. 20 of 2003 concerning the national education system, it is stated that educators are qualified education personnel as teachers, lecturers, counselors, tutors, widyaswara, tutors, instructors, facilitators, and other designations according to their specificity, and participate in providing education.

\subsection{Teacher's Role}

a. Teacher as Educator

Teachers are educators, who become figures, role models and identification for students, and their environment. Therefore, teachers must have certain quality standards, which include responsibility, authority, independence and discipline. The teacher role as an educator (nurturer) is related to increasing the growth and development of children to gain further experiences such as the use of physical health, freedom from parents and other adults, morality of social responsibility, basic knowledge and skills, preparation for marriage and family life, office selection, and personal and spiritual matters. Therefore the teacher task can be called educator and child care. The teacher as the person in charge of child discipline must control every activity of the children so that the level of behavior of the child does not deviate from the existing norms.

\section{b. Teacher as a Mentor}

The teacher's role as a mentor in student learning activities is influenced by various factors, such as motivation, maturity, student-teacher relationship, verbal ability, freedom level, sense of security and teacher communication skills. If the above factors are met, then through learning students can learn well. Teachers should try to make things clear to students and skilled in problem-solving.

Several things must be done by a teacher in learning, namely: illustrating, defining, analyzing, synthesizing, asking, responding, listening, creating trust, providing varied views, providing media for reviewing standard material, adapting learning methods, giving tone feeling, so that learning has maximum strength, teachers must always try to be able to maintain and improve the enthusiasm they have when studying standard material.

\section{c. Teacher as Leader}

Teachers are expected to have personality and knowledge. Teachers become leaders for their students. He will be a priest. The leadership of a teacher will also affect his success in educating and guiding students. So that from these various attitudes, a leadership pattern that is owned by each teacher will be drawn, errors in leading students will have an impact on the failure of a learning process. 


\subsection{Leadership in Physical Health Education (PJOK)}

Education leadership can be broken down into:

a. Formal Leader

A person who is appointed/confirmed as a leader by a decision letter by a higher body or formal educational institution that is intentional, planned and systematic. Leaders in these institutions are usually appointed by a higher body with the position of Head.

b. Informal Leader

Someone who appears when a Head does not function as a leader, that person is accepted by all personal/group members who are as leaders. The person is respected, obeyed and obeyed by his opinions, suggestions and even his orders by all personnel in his environment.

Leadership can also be distinguished according to its nature, namely:

c. Charismatic Leader

Leaders are accepted because their personalities are influential and trusted so that their opinions and decisions are followed. For example, some scholars, traditional leaders, teachers, and others.

d. Symbol Leader

This leader is traditionally recognized as a symbol of the greatness of the group/organization, even though it is not functioning and its leadership is carried out by other people who become assistants. For example; the king who was appointed from generation to generation

e. Headmanship Leader

Leaders who are placed as honorary because of their experience and position in society. For example; The governor was placed as the Chairman of the Indonesian National Sports Committee (KONI).

f. Expert Leader

Leaders who are appointed because they have expertise in certain fields are the burden of the task of an organization so that a professional must be appointed because these tasks cannot be carried out by others.

g. Leading Organizers and Administrators

A leader who because of his skills in organizing many people to work together in realizing the tasks of his group, both in the form of administrative management activities and inoperative management activities.

h. Agitator Leader

Leaders who have to exert pressure, pit each other, create divisions and sharpen disputes by taking advantage of themselves or their group are called agitator leaders.

In leadership, several terms cannot be separated, namely;

1. Leader with activities called leadership

2. Manager with activities called management

3. Administrator with activities called the administration

Quantitatively the three terms above contain different meanings from one another. The difference lies in the breadth and narrowness of the scope of each activity. The following is depicted in the form of a circle: 


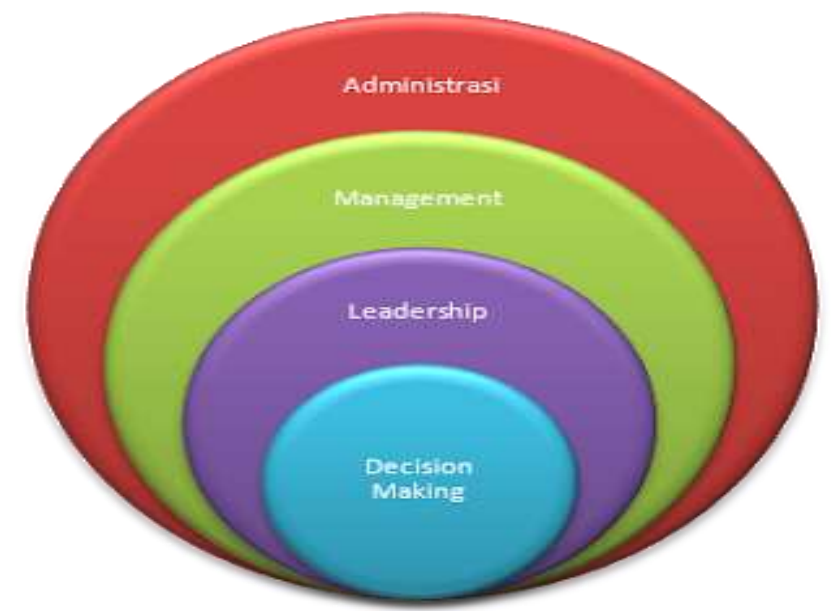

Figure 1. The Difference Lies in the Breadth and Narrowness of the Scope of the Activities

By paying attention to the shape of the circle above, administrative activities cover the broadest scope, next is management and the smallest scope is leadership activities. However, it cannot be denied that all three are cored in decision-making activities or the ability to make decisions. Administrative activities require management and leadership abilities, management activities require leadership abilities that are entirely manifested in the ability to make decisions.

PJOK teachers as leaders of education. Physical Health Education (PJOK) teachers should be the leaders of their students because in terms of age, knowledge, experience and values, these teachers exceed their students. PJOK teachers are people who have competence in teaching and have the task of educating, guiding, training and developing physical education subjects in all types of schools. PJOK teachers are role models that are very worthy of being imitated by students in the life of society, nation and state. The condition of PJOK teachers in their professional duties leads physical education teachers to become leaders. According to Supandi (1992) for this teacher's behavior to have a good effect on the learning process of his students, physical education teachers are required to do the following:

1. Mastering the field both skills and knowledge as well as experience

2. Having the belief that Physical Education does not only develop the physical aspect of students but also helps the development of students as whole human beings.

3. Understanding the physical and spiritual needs and characteristics of students and adjust their learning efforts to these characteristics and needs.

4. Demonstrating a real passion and enthusiasm for work in carrying out tasks to encourage and foster student learning enthusiasm.

5. Demonstrating the fairly high degree of health and physical fitness as an example in daily life.

As leaders, Physical Health Education (PJOK) teachers should be able to handle the class, because the class is an environment that needs to be organized. PJOK teachers must be able to manage their classes by constantly maintaining and creating conditions in the classroom that are challenging and stimulate students to learn, provide a sense of security, satisfaction in helping students to obtain the expected results and goals appropriately by the teaching objectives that have been set, starting from the beginning of the lesson until the end of the lesson.

PJOK teachers are required to have managerial skills in the teaching and learning process of physical education, according to Supandi (1992);

1. Ability to develop lesson plans which are a further elaboration of the curriculum.

2. Organize the teaching and learning process of physical education, namely the ability to utilize resources that support the implementation of long-term and short-term teaching and learning processes. 
3. Control of student learning activities.

4. Assessment, assessment usually deals with learning and the process.

These four skills are basic skills that are very important for physical education teachers, besides that there are many other managerial skills related to the role of physical education teachers as leaders/managers of the teaching and learning process.

\subsection{Leadership Types in PJOK}

In general, there are several types of leadership styles or types, including the following:

1. Authoritarian leadership: "authoritarian" leader acts as a dictator towards his group members, excessive dominance.

2. Laisses-fair leadership: a leader whose existence is only a symbol, a leader who does not provide leadership, allowing subordinates to do as they please. The level of success of the organization is due to the awareness and dedication of its members.

3. Democratic leadership: always trying to stimulate its members to work productively to achieve common goals.

4. Pseudo-democratic leadership: looks like a democratic but pseudo-democratic because it remains authoritarian and only for the interests of certain groups. Autocratic.

\subsection{Teacher Leadership}

Teacher leadership is a process to influence others in which it contains a series of actions or certain behaviors towards the individuals it influences. Teacher leadership is not only limited to the role of teachers in the context of the classroom when interacting with their students but also includes the role of teachers in interacting with principals and peers, while still referring to the same end goal, namely the improvement of student learning processes and outcomes.

There are many models and styles of leadership that teachers can apply in realizing their leadership. Merideth (2000) offers a teacher leadership model called REACH, an acronym for:

- Risk-taking. Teachers try to find challenges and create new processes.

- Effectiveness. Teachers try to do their best, care about the growth and development of their profession and work with heart.

- Autonomy. Teachers display initiative, have independent and responsible thinking.

- Collegiality. Teachers build community capacity and have interactive communication skills.

- Honors. Teachers can demonstrate integrity, honesty, and maintain professional ethics.

Transformational leadership the new leadership, while Sarros and Butchatsky (1996) call it breakthrough leadership. Called a breakthrough because this kind of leader can bring about enormous changes to individuals and organizations by reinventing the character of individuals in the organization or improving the organization, starting the process of creating innovation, reviewing the structure of the organization., processes and organizational values to be better and more relevant, in ways that are interesting and challenging for all parties involved, and try to realize organizational goals that have been considered impossible to implement. Breakthrough leaders understand the importance of fundamental and major changes in their lives and work in achieving the results they desire (Wibawa, 2013).

From various studies conducted, transformational leadership has been proven to affect innovation and creativity. Transformational leadership also has a positive influence on subordinates' effort and satisfaction and can improve ethical behavior (Pounder, 2006). A leadership model is known as Superleadership. Super leadership model is needed in information-based organizations with very fast changes like today. 


\section{Research Methods}

It is understood that the descriptive method, which is a method that seeks to reveal the current state of affairs, to be further analyzed and interpreted because the researcher intends to know the state of something about what and how, how much, to what extent, and so on, then the research is descriptive, namely research that aims to explain or explain events that are currently happening.

In this study, the subjects of the research are the Head and Deputy Principal of SMA Negeri I Kembang Tanjung, the Head of the Curriculum and the PJOK Teachers and each Class Head and Representative from each class in the school with a total of 26 people. The data collection technique is by conducting interviews, observations, and documentation studies. Interview and observation techniques are primary data collection techniques, while documentation studies are secondary data collection techniques. Meanwhile, the data analysis technique is carried out by examining all available data from various sources, namely questionnaires, interviews, field observations, and documents, so that the main points of the project under study related to the research focus can be found. Starting from data display and data verification. For data processing using percentages, then the collection of information is interpreted and at the last stage conclusions can be drawn.

\section{Results and Discussion}

To see whether the research question that was set was "What type of leadership characteristics are generally the most dominant implemented by the PJOK teachers of SMA Negeri I Simpang Tiga". Can be answered perfectly, then the evidence will be measured, through the results of respondents' answers that have been collected, analyzed, processed and tabulated. Research questions can be answered and will be measured through respondents' answers based on the appropriate tables, namely as follows:

Tables 1, 2, 3, 12, 14, and 16 can be concluded that PJOK teachers at SMA Negeri I Simpang Tiga have given positive responses to problems that may arise during PJOK learning hours. Whether it's a situation of student success, failure or problems with learning disorders experienced by students.

While in tables 4, 5, 7, 8, 10 and 11 it can be concluded that the PJOK teachers at SMA Negeri I Simpang Tiga have been able to solve the problems faced by students and PJOK teachers wisely with democratic leadership patterns, deliberation with students in finding a way out to address the various obstacles that exist in the field when the PJOK learning takes place. So the relationship that is built by PJOK teachers with students is a relationship that is between parents and children.

Furthermore, in tables 6, 9, 13, 15, 19, and 20, the respondents' answers have been illustrated and it can be seen that the actions or decisions taken by the PJOK teachers at SMA Negeri I Simpang Tiga are always paying attention to the pros and cons. Against the actions to be taken, thus every action taken must solve the problem at least minimize the problem, not, on the contrary, the problem becomes more developed and more complicated as a result of wrong decision making.

So from various descriptions of the results of field research through questionnaires, it can be answered that in general the leadership model owned by all PJOK teachers at SMA Negeri I Simpang Tiga is a leadership model with "democratic" types, this is evidenced by the results of respondents' answers to 20 (twenty) question items circulated in each questionnaire. This will reflect a truth that occurs in the field, because the selected sample is people who can be responsible for all the consequences for the answers they give. 


\section{Conclusion}

The final part of writing is the stage of making conclusions and the results of research that has been carried out. Furthermore, a refinement of the research will be accompanied by useful suggestions. The authors will present this in sequence as follows:

1. That PJOK teachers at SMA Negeri I Simpang Tiga have given positive responses to problems that may arise during PJOK learning hours. Whether it is a situation of student success, failure or problems with learning disorders experienced by students. This means that the teacher can be wise in all conditions that occur in the field.

2. PJOK teachers at SMA Negeri I Simpang Tiga have been able to solve problems faced by PJOK students and teachers and wisely with democratic leadership patterns, consult with students in finding solutions to address various obstacles that exist in the field when PJOK learning takes place. So the relationship that is built by PJOK teachers with students is a relationship that is between parents and children.

3. The actions or decisions taken by the PJOK teacher at SMA Negeri I Simpang Tiga always pay attention to the pros and cons of the good or bad for the actions to be taken, thus every action taken must solve the problem at least minimize the problem, not, on the contrary, the problem becomes to develop and become more complicated as a result of wrong decision making. So from various descriptions of the results of field research through questionnaires, it can be answered that in general the leadership model possessed by all PJOK teachers at SMA Negeri I Simpang Tiga is a leadership model with "democratic" type.

4. Not all activities carried out by schools must use democratic leadership patterns, because sometimes this attitude will be interpreted by students as an indecisive attitude, especially during practical PJOK lessons, because being a little authoritarian will provoke the enthusiasm of students to dare to try various movements that are considered dangerous so that from the spirit as a trigger students will do or try the technique of the movement.

5. PJOK teachers at SMA Negeri I Simpang Tiga should dare to try leadership patterns that are combined from all existing leadership models, but this must be handled according to the ongoing situation and conditions, as PJOK teachers who has been able to combine various methods in the implementation of PJOK learning both theoretical and practical.

\section{References}

Arif, S. (2019). Influence of Leadership, Organizational Culture, Work Motivation, and Job Satisfaction of Performance Principles of Senior High School in Medan City. Budapest International Research and Critics Institute-Journal (BIRCI-Journal). P. 239-254

Arends, R. I. (2013). Belajar untuk Mengajar: Learning to Teach. Jakarta: Salemba Humanika.

Azis, Abdul Wahab. (2008). Gaya Kepemimpinan Demokratif Penerbit PT Bumi Aksara Jakarta

Ball, D. L., \& Forzani, F. (2010). The Work of Teaching and the Challenge. Journal of Teacher Education, 497.

Irianto, Agus. (2016). Statistik Konsep dasar Aplikasi dan Pengembangannya Penerbit : Pranada Media Grop.Jakrta

James S. Pounder. (2006). Kompetensi Guru Mempengaruhi Gaya Kepemimpinan PT. Remaja Rosdakarya Jakarta

Lutan, Rusli. (2001). Mengajar Pendidikan Jasmani (Pendekatan Pendidikan Gerak Di Sekolah Dasar), Jakarta Depdiknas. 
Nasir Usman. (2007). Manajemen Peningkatan Kinerja Guru. Bandung. Mutiara Ilmu.

Merideth, E.. (2000). Leadership Strategies for Teachers. K-Adult.

Mulyasa, Enco. (2009). Menjadi Guru Profesional. Bandung: PT. Remaja Rosdakarya, Cet, $\mathrm{Ke}-8$

Pounder, James. (2006). Transformational Classroom LeadershipThe Fourth Wave of Teacher Leadership?. Educational Management Administration \& Leadership. 34. 533545. 10.1177/1741143206068216.

Sarros, Butchatsky. (1996) Model-Model Kepemimpinan Penerbit : PT. Remaja Rosdakarya Jakarta.

Sudarmanto. (2009). Kinerja dan Pengembangan Kompetensi SDM. Yogyakarta: Pustaka Pelajar

Supandi. (1992). Strategi Belajar Mengajar Pendidikan Jasmani dan Kesehat. Depdikbud Dirjen Dikti Proyek Pembinaaan Tenaga Pendidikan.

Wibawa, Dwi Ari. "Kepemimpinan Transaksional dan Kepemimpinan Transformasional". http://kppnrantauprapat.net/files/artikel/Kepemimpinan_Transaksional_dan_Transform asional.pdf. diunduh pada tanggal 22 Februari 2014.

Winarno. (2006). Perspektif Pendidikan Jasmani dan Olahraga. Penerbit : Laboratorium Ilmu Keolahragaan Fakultas Ilmu Pendidikan Universitas Negeri Malang

https://www.dosenpendidikan.co.id/peran-guru/ .

https://www.arhamsyahban.com/2016/09/kepemimpinan-dalam-pendidikan-jasmani.html.

https://akhmadsudrajat.wordpress.com/2013/05/02/kepemimpinan-guru-teacher-leadership$2 /$. 